\title{
Dwugłos w sprawie dopuszczalności badań naukowych z wykorzystaniem ludzkiego materiału biologicznego. Problemy prawne z perspektywy etycznej
}

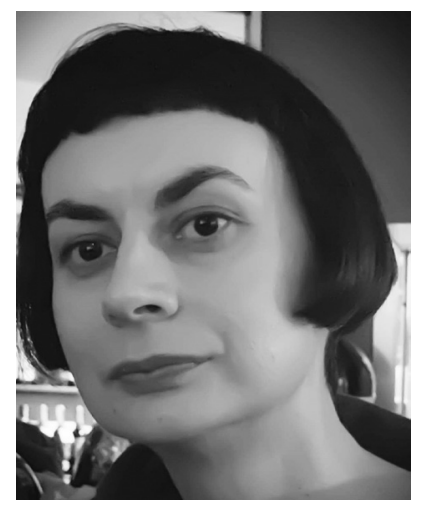

Olga Dryla

Doktor habilitowany nauk humanistycznych, profesor Uniwersytetu Jagiellońskiego, pracuje w Zakładzie Badań nad Etyką Zawodowa Instytutu Filozofii UJ, od 2010 roku członek Polskiego Towarzystwa Bioetycznego. Wśród jej zainteresowań badawczych na pierwszy plan wysuwa się problematyka bioetyczna, a zwłaszcza etyczne aspekty badań naukowych $z$ udziałem ludzi (i wykorzystaniem ludzkich szczątków), genetyki klinicznej oraz problematyka dopuszczalności tzw. medycznego doskonalenia.

$\bowtie$ olga.dryla@uj.edu.pl

https://orcid.org/oooo-0oo2-9392-5146

\author{
Double Voice on the Admissibility \\ of Scientific Research Using Human \\ Biological Material. Legal Issues \\ and Ethical Perspective
}

\begin{abstract}
The text is devoted to consideration on the morally desirable way of clarifying the ambiguities identified in a previous part of the double voice. So it contains deliberations on meaning and authority of biological material donor informed consent. Considering research on human corpses the author focus on two questions: why deceased patient's premortem preferences should be taken into account at all and whether "an advance research directives" of that kind should take a form opt-in or opt-out arrangements? Whereas when it comes to research on biological samples the most important question is what type of actual - not presumed-consent meet ethical standards.
\end{abstract}

\section{Słowa kluczowe: zgoda, ludzki materiat biologiczny, badania Key words: consent, human biological material, research https://doi.org/10.32082/fp.v0i3(59).341}

\section{Wprowadzenie}

W pierwszym z tekstów dwugłosu na temat dopuszczalności badań naukowych z wykorzystaniem ludzkiego materiału biologicznego szczegółowo omówiono polskie regulacje prawne dotyczące zasad wykorzystywania ludzkich tkanek, części ciała oraz zwłok w badaniach nauko- wych. Ponieważ jednak większość owych regulacji nie oferuje jednoznacznych rozstrzygnięć, zasady wykorzystywania ludzkiego materiału biologicznego w celach naukowych pozostają w sferze systemowo uzasadnianych interpretacji. Ten stan rzeczy prowokuje rozważania na temat pożądanych - z etycznego punktu 
widzenia - sposobów doprecyzowania tych niejasności. Na pierwszy plan wysuwa się tu niewątpliwie kwestia (przedśmiertnej) świadomej zgody podmiotu na (pośmiertne) wykorzystanie jego tkanek, części ciała lub zwłok w badaniach naukowych ${ }^{1}$. Treść prezentowanego tekstu została więc wyznaczona przez następujące pytania: czy któraś z wymienionych kategorii badań wymaga uprzedniej zgody dawcy szeroko rozumianego materiału biologicznego, a jeśli tak, to jaka forma świadomej zgody będzie najwłaściwsza? Przy czym skoncentruję się tu przede wszystkim na badaniach naukowych wykorzystujących ludzkie zwłoki oraz tkanki, ponieważ wnioski dotyczące badań z użyciem części ciała będą w gruncie rzeczy analogiczne.

Na wstępie warto rozstrzygnąć pewną wątpliwość. Otóż intuicje dotyczące właściwego - z etycznego punktu widzenia - sposobu przeprowadzania badania naukowego będą się zasadniczo różnić w zależności od tego, jaki materiał ma być w nim wykorzystany: będą inne, jeśli chodzi o tkanki pozyskane w procesie terapeutycznym, a inne - jeśli o zwłoki z bijącym ser$\mathrm{cem}^{2}$. Te wstępne intuicje mogą prowadzić do wniosku, że rozważania na temat świadomej zgody dawcy (czy donatora) mają sens, gdy mowa o użyciu zwłok bądź części ciała kojarzonych z tożsamością osobową i człowieczeństwem - tymi szeroko rozumianymi szczątkami podmiot powinien móc bowiem dysponować zgodnie z własnym uznaniem - ale nie w odniesieniu do użycia tkanek pozyskanych podczas pobrań, biopsji itp. Faktycznie wykorzystywanie tzw. bezużytecznych resztek w badaniach medycznych nie było przedmiotem specjalnego namysłu; do niedawna nie widziano żadnego - również moralnego - problemu w ich używaniu do celów naukowych (zwłaszcza że dzięki temu to, co z reguły bezwartościowe, znajdowało jednak

1 Jest rzeczą oczywistą, że w przypadku tkanek lub części ciała pozyskanych przy okazji rozmaitych procedur terapeutycznych (od pobrania krwi poczynając, na amputacjach kończąc) równie dobrze może chodzić o pośmiertne wykorzystanie materiału biologicznego, jak o badania przeprowadzane za życia dawcy.

2 M.R. Wicclair, M.A. De Vita, Oversight of Research Involving the Dead, „Kennedy Institute of Ethics Journal” 2004, t. 14, nr 2, s. 143-164. zastosowanie) $)^{3}$. Niemniej niezależnie od tych całkiem naturalnych intuicji trzeba przyjąć do wiadomości, że wraz z rozwojem genetyki sytuacja diametralnie się zmieniła. Każda próbka biologiczna jest nośnikiem ogromnej ilości danych na temat dawcy i chociażby $z$ tego powodu należy uznać, że wykorzystanie w badaniach nawet tzw. bezużytecznych resztek biologicznych powinno się odbywać wyłącznie pod warunkiem uzyskania świadomej zgody dawcy. Problematyka badań naukowych z wykorzystaniem tkanek - a zwłaszcza właściwej formy świadomej zgody na wykorzystanie próbek biologicznych - powróci w dalszej partii tekstu, w pierwszej kolejności zostaną natomiast omówione etyczne aspekty prowadzenia badań na ludzkich zwłokach, ze szczególnym uwzględnieniem roli przedśmiertnej woli podmiotu.

\section{Badania naukowe z wykorzystaniem ludzkich zwłok - uwagi wstepne}

Na potrzeby tekstu przyjmuję założenie, iż wykorzystywanie zwłok w procedurach naukowych i dydaktycznych jest nie tylko potrzebne, ale i dopuszczalne. Badania naukowe dostarczają cennych danych wykorzystywanych w całym spektrum dziedzin wiedzy (a co za tym idzie - praktyki); wystarczy wymienić medycynę, kryminalistykę czy balistykę, których rozwój jest w zasadzie ufundowany na różnego rodzaju eksperymentach z użyciem ludzkich zwłok. Podstawą uzasadnienia dopuszczalności tych wszystkich praktyk jest niezaprzeczalny wynikający z nich pożytek: wolno wykorzystywać ciała zmarłych do badań naukowych, ponieważ badania te służą żywym. Warto zaznaczyć, że zakres tego potencjalnego pożytku niepomiernie wzrasta, jeśli wziąć pod uwagę badania na zmarłych z bijącym sercem. Tutaj w grę mogłaby wchodzić m.in. eksperymentalna farmakologia i chirurgia, nanotechnologia czy testowanie urządzeń medycznych, czyli albo badania, których nie wolno by było przeprowadzić na żywych probantach, albo badania, których przeprowadzenie $\mathrm{z}$ udziałem zmarłych z bijącym sercem oszczędziłoby żywym probantom (w tym zwierzętom)

3 S.C. Lawrence, Beyond the Grave - The Use and Meaning of Human Body Parts. A Historical Introduction, „Faculty Publications, Department of History, University of Nebraska - Lincoln” 1998, January, passim. 
bólu i cierpienia ${ }^{4}$. Niemniej, wziąwszy pod uwagę opisany powyżej stan polskiego prawodawstwa, prowadzenie rozważań nad warunkami dopuszczalności wykorzystywania w badaniach zwłok z bijącym sercem wydaje się kontrproduktywne. Skoro brak klarownych wskazówek dotyczących pozyskiwania zwłok do celów naukowych i dydaktycznych, nie ma sensu zastanawiać się nad zasadami pozyskiwania szczególnej kategorii zwłok (z bijącym sercem). Wypada zająć się pożądanym kierunkiem doprecyzowania tych najogólniejszych zasad.

Nie wchodząc w zawiłości polskich regulacji prawnych, warto zestawić ze sobą następujące, płynące $z$ ich analizy wnioski: wykorzystanie zwłok do celów naukowych jest możliwe przy założeniu przedśmiertnej zgody podmiotu, przy czym nie jest jasne czy ma chodzić o zgodę rzeczywistą, czy domniemaną. Innymi słowy, nie wiadomo, czy podmiot musi przed śmiercią zadeklarować chęć przeznaczenia ciała na cele naukowe (model opt-in), czy też wystarczy, że nie wyrazi jawnego sprzeciwu (model opt-out). W kontrze do tego jednoznacznego - na najogólniejszym poziomie - przekazu, znajdujemy jednak informację, iż tzw. „zwłoki niepochowane", zwłoki, po które nikt się nie zgłosi, można decyzją administracyjną przekazywać do celów naukowych uczelniom medycznym. Wyraźnie rysuje się więc porządek dociekań wyznaczany przez kolejne pytania: (1) czy należy brać pod uwagę przedśmiertną wolę zmarłego dotyczącą pośmiertnych losów jego ciała; jeśli tak, to (2) dlaczego i (3) czy wobec braku wyrażonego explicite sprzeciwu można domniemywać konkretną preferencję (model opt-out), czy też wiążące powinny być wyłącznie explicite sformułowane dyspozycje (model opt-in). Kolejne ustalenia pozwolą krytycznie spojrzeć na wspomnianą praktykę dotyczącą zwłok niepochowanych.

Negatywna odpowiedź na pierwsze z postawionych pytań pozwala skojarzyć zwolenników tego podejścia $\mathrm{z}$ tak zwanym modelem rutynowego pozyskiwania narządów do przeszczepów (tyle że w tym wypadku

4 Por. np. M.R. Wicclair, Ethics and Research with Deceased Patients, „Cambridge Quarterly of Healthcare Ethics” 2008, t. 17, s. 87-97; R.D. Pentz i in., Ethics Guidelines for Research with the Recently Dead, „Nature Medicine” 2005, t. 11, nr 11, s. 1145-1149. chodziłoby oczywiście o rutynowe pozyskiwanie zwłok do badań). Wysuwane na jego poparcie argumenty (m.in. z przeciwdziałania bezproduktywnemu powrotowi do zbiornika biomasy, z zasobu naturalnego oraz ze spłaty długu zaciągniętego u społeczeństwa ${ }^{5}$ ) odnoszą się do bezpośredniej i niemal natychmiastowej korzyści, jaką odniosłoby nieporównanie więcej osób (biorców), o ile wprowadzono by właśnie taki model pozyskiwania narządów. Wykorzystanie zwłok w celach naukowych tej gwarancji nie daje: nie jest tak oczywiste, że prawo do rutynowego pozyskiwania zwłok dawałoby szanse na jakiś skokowy przyrost płynącej z badań korzyści, która zresztą - co równie istotne - $\mathrm{i}$ tak nie byłaby bezpośrednim dobrem jakiegoś konkretnego podmiotu. Z punktu widzenia bieżących rozważań istotny jest jednak inny argument zwolenników prawa do swobodnego (nieograniczonego jakimkolwiek odniesieniem do przedśmiertnej woli podmiotu) dysponowania zwłokami: martwych nie trzeba bronić przed chorobą, śmiertelnością, bólem, stresem i cierpieniem ${ }^{6}$. Na bardziej ogólnym poziomie: zmarli nie mogą doświadczyć żadnej szkody, nie mają interesów, praw ani dóbr ${ }^{7}$, zmarłym nie można zaszkodzić ani ich skrzywdzićs.

\subsection{Szacunek dla zmartych}

Dyskusja dotycząca możliwości wyrządzenia tzw. pośmiertnej szkody jest, jak wiadomo bogata, rozbudowana ${ }^{9} \mathrm{i}$ bez wątpienia teoretycznie istotna. Niemniej

5 Por. K. Szewczyk, Bioetyka, Pacjent w systemie opieki zdrowotnej, Warszawa 2009, s. 151.

6 K.V. Iserson, Life versus Death. Exposing a Misapplication of Ethical Reasoning, ,Journal of Clinical Ethics” 1994, t. 5, s. 262.

7 J. Harris, Organ Procurement. Dead Interests, Living Needs, „Journal of Medical Ethics” 2003, t. 29, s. 130-134.

8 Przywołuję stanowisko M.R. Wicclair, Ethics and Research with Deceased Patients, „Cambridge Quarterly of Healthcare Ethics” 2008, t. 17, s. 87-97.

9 Por. np. J. Feinberg, The Moral Limits of the Crime Law, t. 1: Harm to Others, New York [Oxford University Press] 1987, s. 78-94; E. Partridge, Posthumous Interests and Posthumous Respect, „Ethics” 1981, t. 91, nr 2, s. 243-264; B. Baum Levenbook, Harming Someone after His Death, „Ethics” 1984, t. 94, nr 3, s. 407-419; B. Baum Levenbook, Harming the Dead, Once Again, „Ethics” 1985, t. 95, nr 1, s. 162-164; 
dla pytania o właściwe reguły pozyskiwania zwłok do celów naukowych ma znaczenie marginalne. Nie wolno zapominać, że poszukujemy racji, które pozwoliłyby na pożądane doprecyzowanie i/lub modyfikację zasad prawnych faktycznie regulujących procedury pozyski- zwłoki (i szczątki) ludzkie powinny wyrażać szacunek dla zmarłych, została uznana w tej sferze za naczelną zasadę etyczną ${ }^{10} \mathrm{i}$ zajmuje poczesne miejsce w kodeksach regulujących prowadzenie badań naukowych na ludzkich zwłokach i szczątkach ${ }^{11}$. Wiadomo, że zmar-

\section{Wiadomo, że zmarłym nie można przysporzyć} cierpienia ani bólu, nie wiadomo, czy można ich skrzywdzić lub im zaszkodzić, ale na pewno należy traktować ich z szacunkiem. Jednym z przejawów tego szacunku jest poszanowanie ich domniemanych lub wyrażonych wprost przedśmiertnych preferencji.

wania zwłok. A pożądany kierunek modyfikacji jest wyznaczany (przynajmniej również) przez kontekst społeczno-kulturowy, czyli zarówno zespół przedrefleksyjnych, rozpowszechnionych intuicji, jak i obowiązujące już rozstrzygnięcia dotyczące spraw w jakimś stopniu analogicznych. A zarówno rozpowszechnione intuicje, jak i rozstrzygnięcia w kwestiach do pewnego stopnia analogicznych jednoznacznie wskazują, że przedśmiertnych dyspozycji zmarłego z reguły nie należy ignorować, a wyznawane przez niego wartości z reguły powinny być uwzględniane: niestosowną rzeczą będzie urządzenie religijnego pogrzebu apostacie, niedopuszczalną rzeczą będzie zignorowanie zapisów testamentu. Cały zespół owych intuicji i rozstrzygnięć można opatrzyć nagłówkiem: „Szacunek dla zmarłych”. Zasada głosząca, iż badania naukowe wykorzystujące

J.C. Callahan, On Harming the Dead, „Ethics” 1987, t. 97, nr 2, s. 341-352; L.B. Andrews, Do the Dead Have Interests? Policy Issues for Research After Life (with D. Nelkin), „American Journal of Law \& Medicine” 1998, t. 24, nr 261, http://scholarship.kentlaw.iit.edu/fac_schol/10 (dostęp 29.07.2019); T.M. Wilkinson, Last Rights. The Ethics of Research on the Dead, „Journal of Applied Philosophy” 2002, t. 19 , nr 1, s. 31-41. łym nie można przysporzyć cierpienia ani bólu, nie wiadomo, czy można ich skrzywdzić lub im zaszkodzić, ale na pewno należy traktować ich z szacunkiem. Jednym z przejawów tego szacunku jest zaś zapewne poszanowanie ich domniemanych lub wyrażonych wprost przedśmiertnych preferencji.

W tym miejscu warto poświęcić nieco uwagi powodom, dla których to właśnie szacunek został uznany za naczelną wartość określającą właściwy stosunek żywych do zmarłych, oraz praktycznym implikacjom takiego rozstrzygnięcia. Mechanizm, który mógł uczynić z szacunku wartość preferowaną tam, gdzie przedmiotem szeroko rozumianych działań są ludzkie

10 Por. np. R.D. Pentz i in., Ethics Guidelines..., s. 1145-1149; M.R. Wicclair, Ethics and Research with Deceased Patients, „Cambridge Quarterly of Healthcare Ethics” 2008, t. 17, s. $87-97$.

11 Por. np. The National Committee for Research Ethics on Human Remains, Guidelines for Research Ethics on Human Remains, The Norwegian National Research Ethics Committees, English edition, July 2016; British Association of Biological Anthropology and Osteoarchaeology, Code of Ethics, BABAO Working Group for ethics and practice 2010 https://www.babao.org.uk/assets/Uploads-to-Web/ code-of-ethics.pdf (dostęp 29.06.2019). 
zwłoki, przekonująco zaprezentował Ernest Partridge w swoim artykule Posthumous Interests and Posthumous Respect ${ }^{12}$. Jest to artykuł polemiczny wobec tekstów broniącego koncepcji pośmiertnej szkody Joela Feinberga ${ }^{13}$, zatem niezaprzeczalną zaletą zaproponowanego wyjaśnienia jest to, iż abstrahuje ono od tej nieoczywistej koncepcji. Zdaniem Partridge'a szacunek dla zmarłych wraz z jednym z jego konstytutywnych przejawów - poszanowaniem przedśmiertnych dyspozycji osób zmarłych - można niejako wyprowadzić z analizy kryteriów osobowości moralnej oraz z klasycznej umowy społecznej.

Osoba to byt pojmujący siebie jako istotę czującą, refleksywną, ograniczoną pod względem fizycznym i czasowym, byt, który postrzega siebie jako świadomy, trwający w czasie podmiot, jest więc w stanie wykraczać (w wyobraźni) poza czas i miejsce swojego biologicznego istnienia oraz - w tym miejscu zaczynamy już mówić o osobowości moralnej - dostrzegać tam rzeczy dla siebie ważne (stany rzeczy, idee, instytucje). W przypadku dojrzałej osoby moralnej wymienione właśnie warunki wytwarzają także zdolność do moralnej abstrakcji, czyli umiejętność wyprowadzania z jednostkowych konkretnych przypadków ogólnych kategorii moralnych oraz umiejętność ich bezstronnej oceny. Osoba moralna konstruuje plany wykraczające poza czas i miejsce swojego biologicznego istnienia, musi zatem polegać na kontraktach i umowach. Sprowadzając ten ogólny schemat do zagadnień będących przedmiotem rozważań: człowiek konstruuje plany dotyczące pośmiertnych losów swojego ciała, ponieważ jest w stanie antycypować i ocenić je już teraz, jeśli zaś chodzi o ich realizację, musi polegać na umowie, czyli nałożonym na innych zobowiązaniu. Dlaczego jednak inni mają być zobowiązani do realizacji przedśmiertnych planów (preferencji, dyspozycji itp.) zmarłych? Ponieważ - jako osoby moralne w podanym powyżej znaczeniu - są zainteresowani tym, by kiedyś zrealizowano ich własne przedśmiertne preferencje i dyspozycje. Obowiązki wobec zmarłych są

12 E. Partridge, Posthumous Interests and Posthumous Respect, „Ethics” 1981, t. 91, nr 2, s. 243-264.

13 Por. np. J. Feinberg, Harm and Self-Interest (w:) P.M.S. Hacker, J. Raz (eds.), Law, Morality and Society. Essays in Honour of H. L. A. Hart, Oxford 1977, s. 284-308. więc pochodną praktyk, które większość ludzi uznaje za warte podtrzymania ze względu na własne, dotyczące ich samych preferencje. Powinniśmy szanować zmarłych, także poprzez realizację ich przedśmiertnych dyspozycji, ponieważ chcemy, by w przyszłości z szacunkiem obchodzono się z naszymi zwłokami i realizowano nasze przedśmiertne zalecenia.

\subsection{Poszanowanie przedśmiertnych dyspozycji}

Skoro dysponujemy dość przekonującym wyjaśnieniem powodów, dla których to szacunek ustanowiono preferowaną wartością w relacji żywych do zmarłych, czas bliżej przyjrzeć się stanowiącemu jej konieczną implikację obowiązkowi poszanowania przedśmiertnych decyzji. Zrąb proponowanej konstrukcji będzie stanowić tzw. formalny obowiązek poszanowania przedśmiertnych życzeń ${ }^{14}$, którego treściowym wypełnieniem jest przedśmiertna preferencja zmarłego. $\mathrm{Na}$ najbardziej ogólnym poziomie wyrazem szacunku dla zmarłego jest więc poszanowanie jego dyspozycji. Jeśli podmiot wyraził swoje preferencje za życia, wiadomo, co należy zrobić z ciałem po jego śmierci; w tym miejscu jedynie zasygnalizuję, iż nawet tak na pierwszy rzut oka klarowna sytuacja może przysparzać pewnych problemów. Co się jednak dzieje z obowiązkiem formalnym wtedy, gdy żadnych dyspozycji nie pozostawiono? Skoro jego treściowym wypełnieniem nie może być wyrażona preferencja, staje się nim domniemanie preferencji, przy czym zbiór preferencji, które wolno domniemywać, jest ściśle ograniczony, a wyznaczają go rozpowszechnione w danym kręgu społeczno-kulturowym, usankcjonowane poglądy na temat godnego traktowania zwłok. W naszym kręgu społeczno-kulturowym zakres domniemanych preferencji obejmuje formę pochówku oraz dawstwo organów: rodzinie (lub innym osobom odpowiedzialnym) wolno domniemać, iż zmarły za życia preferował taką, a nie inną - spośród dopuszczanych przez prawo formę pochówku, lekarzom wolno domniemać, że preferował wykorzystanie organów do ratowania życia/ zdrowia kogoś, kto czeka na przeszczep. Wpisanie

14 Prezentowana propozycja to przeformułowanie koncepcji zawartej w tekście Y.M. Barilana, Bodyworlds and the ethics of using human remains: a preliminary discussion, „Bioethics” 2006, t. 20, nr 5, s. 233-247. 
pewnych procedur w model opt-out najwyraźniej wskazuje, iż należą one do zbioru preferencji, które wolno domniemywać, o ile podmiot nie pozostawił w tej kwestii żadnej jasnej dyspozycji. Wolno domniemywać, że podmiot preferował kremację, wolno domniemywać, że chciał być dawcą organów, o ile za życia nie sprzeciwił się którejś z tych procedur. z innymi, mocniejszymi obowiązkami. W praktyce oznacza to, iż indywidualna dyspozycja może modyfikować wspomniany powyżej zbiór domniemanych preferencji na dwa sposoby: podmiot może skutecznie wykluczyć pewne (acz nie wszystkie) preferencje, które wolno by było domniemać, lub wybrać pewne (acz nie wszystkie) procedury niemieszczące się w zbiorze pre-

\section{Wpisanie pewnych procedur w model opt-out} wskazuje, że należą one do zbioru preferencji, które wolno domniemywać, o ile podmiot nie pozostawił w tej kwestii żadnej jasnej dyspozycji.

Dla pełnego obrazu należy poświęcić nieco uwagi również tym przypadkom, w których istnieje jednoznaczna przedśmiertna dyspozycja zmarłego. Okazuje się, że obowiązek realizacji takich dyspozycji nie jest obowiązkiem bezwzględnym: nie tylko nie musimy, ale wręcz nie wolno nam zrealizować żądania kogoś, kto chciałby, aby jego zwłoki zostały wrzucone do śmietnika, porzucone w lesie czy spalone na miejskim rynku. Analiza źródeł i statusu tych ograniczeń to temat na odrębny, obszerny tekst. W tym miejscu wystarczy jedynie zaznaczyć, że wyznaczenie granic autonomicznego wyboru wcale nie podważa mocy obowiązku poszanowania autonomicznych decyzji; w gruncie rzeczy należałoby mówić o mocnym obowiązku poszanowania tych autonomicznych wyborów, które mieszczą się w sferze wyznaczonej przez cały zespół uwarunkowań moralno-prawno-kulturowych. Zignorowania prośby o porzucenie zwłok na śmietniku - podobnie jak zignorowania prośby o nieinformowanie o planowanym morderstwie - nie będziemy rozpatrywać w kontekście naruszenia czyjejś autonomii, ale w kontekście przeciwdziałania naruszeniu innych ważnych norm moralno-prawnych. Innymi słowy, mamy tu do czynienia z klasycznym przykładem obowiązku prima facie: należy szanować przedśmiertne dyspozycje dotyczące pośmiertnych losów ciała, o ile realizacja tego obowiązku nie wchodzi w konflikt ferencji, które wolno by było domniemać. Mogę skutecznie wykluczyć kremację (choć nie mogę wykluczyć pochówku w ogóle), mogę też wybrać donację ciała do celów dydaktycznych (choć nie mogę wybrać spalenia na miejskim rynku).

\subsection{Opt-in czy opt-out}

Przedstawiona w poprzedniej części dwugłosu analiza polskich regulacji prawnych wskazuje na fundamentalną niejasność w kwestii statusu przekazywania zwłok do celów naukowych: nie wiadomo, czy są to procedury, które wchodzą w zakres dopuszczalnych domniemań, czy też procedury, które można wybrać w sformułowanej wprost dyspozycji. Nie ma w zasadzie wątpliwości, że badania naukowe - oczywiście przeprowadzane pod odpowiednimi rygorami - nie naruszają godności zmarłych; nie jest natomiast jasne, czy tego typu procedury powinny, podobnie jak pobrania transplantacyjne, być przeprowadzane w modelu opt-out, czy może właściwszy będzie jednak model opt-in. W poświęconej temu zagadnieniu dyskusji zwraca się uwagę na trzy istotne różnice pomiędzy donacją do celów transplantacyjnych a donacją do celów badawczych; sprawiają one, że o ile w przypadku przeszczepów za właściwy można uznać model domniemanej zgody (opt-out), o tyle w przypadku przekazywania zwłok na cele naukowe należy jednak oczekiwać rze- 
czywistej przedśmiertnej zgody podmiotu $(o p t-i n)^{15}$. Warto je uporządkować, przyjmując za kryterium siłę związanych z nimi moralnych racji. Po pierwsze zwraca się uwagę, że pobranie organów do przeszczepu w żaden sposób nie wpływa na plany pogrzebowe: pochówek nie zostanie odroczony, nie dojdzie też do dostrzegalnej dla żałobników ingerencji w zewnętrzny wygląd zmarłego. Wykorzystanie zwłok w badaniach naukowych, oględnie rzecz ujmując, nie daje tej gwarancji. Argument odwoływałby się więc wyłącznie do dyskomfortu psychicznego bliskich zmarłego; jeśli przywołuje się go w kontekście rozważań nad obowiązkiem poszanowania przedśmiertnych decyzji osoby zmarłej oraz zakresu dopuszczalnych domniemań dotyczących jej niewyrażonych preferencji - można go uznać najwyżej za argument towarzyszący, na pewno nie rozstrzygający. Trudno byłoby uzasadnić pogląd, że zakres tego, co jest lub mogłoby być treścią mojego zobowiązującego dla innych wyboru, należy a priori - niezależnie od mojej opinii - ograniczyć ze względu na komfort psychiczny moich bliskich. Po drugie, jeśli chodzi o transplantacje, istnieje permanentna dysproporcja pomiędzy - nazywając rzecz po imieniu - podażą a popytem. Dostępnych organów jest zdecydowanie za mało w stosunku do potrzeb medycznych; wydawałoby się więc, że mamy tu do czynienia z czysto pragmatycznym argumentem przemawiającym na rzecz wpisania donacji transplantacyjnych w model opt-out. Ale przeciez - w tym miejscu staje się jasne, że względy pragmatyczne mają swoje implikacje moralne - każdy przeszczep to czyjeś bezpośrednie dobro w postaci szansy na uratowanie życia lub zdrowia bądź też poprawy tzw. jakości życia. Istnieje więc ważny powód, by uznać, że możliwość przysporzenia tak istotnego dobra konkretnej osobie będzie jedną $\mathrm{z}$ domniemanych przedśmiertnych preferencji. W przypadku badań naukowych wykorzystujących ludzkie zwłoki bez wątpienia nie ma mowy o czyjejś bezpośredniej korzyści, nie ma mowy o dobru w postaci uratowanego życia lub zdrowia, racja przemawiająca za wdrożeniem modelu opt-out byłaby więc znacznie słabsza, opierałaby się bowiem jedynie na zwiększeniu

15 Por. np. M.R. Wicclair, Ethics and Research with Deceased Patients, „Cambridge Quarterly of Healthcare Ethics” 2008, t. 17, s. $87-97$. szans na przysporzenie uogólnialnej wiedzy naukowej. Rozstrzygająca wydaje się tu jednak trzecia podnoszona różnica. Model domniemanej zgody (opt-out) opiera się na założeniu, iż brak sprzeciwu wobec pewnych procedur nie jest wyrazem niedbalstwa czy niewiedzy, ale świadomą decyzją podmiotu. Zaś zdecydowanie bardziej prawdopodobne jest to, że świadomą decyzją jest brak sprzeciwu wobec pośmiertnej donacji, niż to, że jest nią brak sprzeciwu wobec wykorzystania zwłok do celów naukowych ${ }^{16}$. Spektrum badań rozciąga się pomiędzy analizą tkanki pobranej podczas autopsji a badaniami z wykorzystaniem zwłok z bijącym sercem (trudno nawet przewidzieć, jakie badania będą prowadzone za kilka, kilkanaście lat). Prawdopodobnie tylko nieliczni rzeczywiście zdawaliby sobie sprawę z tego, że brak sprzeciwu na wykorzystanie ich zwłok do celów naukowych umożliwiałby podtrzymywanie krążenia (po stwierdzeniu śmierci mózgu) np. w celu testowania urządzeń medycznych czy przeprowadzania eksperymentalnych zabiegów chirurgicznych.

Istnieją zatem powody, by uznać, iż w przeciwieństwie do pobrań transplantacyjnych przekazanie ciała do celów naukowych powinno się dokonywać wyłącznie na podstawie rzeczywistej przedśmiertnej zgody podmiotu. Za takim rozwiązaniem przemawia również dokonane już rozstrzygnięcie w kwestii analogicznej: donacja zwłok do celów dydaktycznych odbywa się właśnie na podstawie explicite wyrażonej przedśmiertnej woli podmiotu (z zastrzeżeniem, do którego powrócę poniżej). W trosce o zupełność prezentacji należy zaznaczyć, iż w literaturze przedmiotu bywa też rozważana trzecia (obok rzeczywistej i domniemanej zgody podmiotu) możliwość. Niektórzy autorzy sugerują, że brak przedśmiertnej dyspozycji dotyczącej przekazania zwłok do celów naukowych oznacza, iż podmiot przynajmniej godził się, by decyzję podjęła rodzina ${ }^{17}$. Pomijając zasadność takiego domysłu, traktując tę propozycję poważnie, naru-

16 Por. też R.D. Pentz i in., Ethics Guidelines......, s. 1145-1149.

17 Por. np. M.R. Wicclair, Informed Consent and Research Involving the Newly Dead, „Kennedy Institute of Ethics Journal” 2002, t. 12, s. 351-362; R.D. Pentz i in., Ethics Duidelines..., s. 1145-1149; M.R. Wicclair, Ethics and Research with Deceased Patients, „Cambridge Quarterly of Healthcare Ethics” 2008, t. 17 , s. $87-97$. 
szamy de facto same fundamenty, na których oparto specjalny status szacunku w relacji żywych do zmarłych: przypomnijmy, chodziło o szczególne zasady funkcjonowania podmiotu moralnego, o jego antycypacje i jego opinię dotyczącą pośmiertnych losów jego ciała. Oczywiście scedowanie decyzji na osoby bliskie mogłoby się stać jedną z opcji, które podmiot może wybrać (opt-in), niemniej włączając ją do zbioru dopuszczalnych domniemanych preferencji godzilibyśmy się na to, że niejako automatycznie decydującego znaczenia nabierają preferencje kogoś innego niż sam podmiot. Co więcej, przyjęcie takiego rozwiązania w przypadku donacji zwłok do celów naukowych po pierwsze rodziłoby przypuszczenie, że należałoby je stosować także do donacji dla celów dydaktycznych, a po drugie - i ta obserwacja jest chyba rozstrzygająca - w zasadzie podważyłoby sensowność modelu opt-out: skoro podmiot nie pozostawił żadnych dyspozycji (np. co do ewentualnych pobrań organów), kontrowersyjny charakter niektórych z nich formularz zgody powinien mieć formę listy możliwych sposobów wykorzystania zwłok (tzw. checklist), gdzie dawca zaznacza te, na które się zgadza.

\subsection{Zwłoki niepochowane}

W tym miejscu nieuchronnie powraca wątek niepokojącego wyłomu, jaki w polskich regulacjach stanowi przyzwolenie na przekazywanie uczelniom medycznym zwłok osób niepochowanych. W literaturze przedmiotu można doszukać się dwóch wyjaśnień tej zaskakującej praktyki: pierwsze odwołuje się do pewnych zaszłości historycznych i pozwala określić omawianą praktykę mianem swego rodzaju atawizmu prawno-kulturowego, drugie natomiast odwołuje się do uczuć bliskich osoby zmarłej. Krótka prezentacja obu wyjaśnień pozwoli wykazać, iż możliwość przekazywania decyzją administracyjną zwłok niepochowanych uczelniom medycznym powinna zostać wykluczona.

\section{Model domniemanej zgody (opt-out) opiera się} na założeniu, ze brak sprzeciwu wobec pewnych procedur nie jest wyrazem niedbalstwa czy niewiedzy, ale świadomą decyzją podmiotu.

załóżmy, że chciał, by decyzję podjęła rodzina. I tym samym zmuszeni jesteśmy przyjąć mocne - i nieuzasadnione - założenie, że jedyną domniemaną preferencją podmiotu zawsze będzie pozostawienie decyzji w rękach rodziny.

Reasumując: z powyższych rozważań wynika, iż realizacja nadrzędnego zobowiązania do poszanowania zmarłych wymaga, by wykorzystanie zwłok w badaniach naukowych odbywało się wyłącznie na podstawie przedśmiertnej zgody podmiotu, a mocne racje przemawiają za tym, by zastosować tu model zgody rzeczywistej, a nie domniemanej. Preferowane zatem powinno być rozwiązanie analogiczne, jak w przypadku donacji zwłok do celów dydaktycznych. Ze względu na zróżnicowanie celów badawczych oraz
Rozpocznijmy od prawno-kulturowej zaszłości. W średniowieczu i wczesnej nowożytności pohańbienie (rozczłonkowanie) zwłok było integralną częścią kary zasądzanej wobec najgorszych zbrodniarzy. Uogólniając, sposób traktowania zwłok był pochodną przedśmiertnego statusu podmiotu: inaczej traktowano zwłoki świętych, inaczej kryminalistów; szczątki pierwszych czczono, szczątki drugich „karano” ${ }^{18}$. W połowie XVIII w. rozczłonkowanie - tu już pod postacią przeprowadzenia publicznej sekcji zwłok traktowano jako element wyroku śmierci. Rozczłonkowanie - niezależnie od tego, czy związane z celami dydaktyczno-naukowymi - jako największa zniewaga

18 S.C. Lawrence, Beyond the Grave... 
dla integralności i tożsamości ciała ${ }^{19}$, stanowiło przejaw sprawiedliwości retrybutywnej. Bezpośrednią kontynuacją tradycji, zgodnie z którą pośmiertne losy ciała zależą od wartości, jaką człowiek prezentował za życia, był British Anatomy Act z 1832 r., który pozwalał administratorom szpitali i przytułków na wydawanie akademiom medycznym zwłok osób, które zmarły, pozostając pod opieką tych instytucji lub na ulicach, nej woli). Zdaniem zwolenników tego wyjaśnienia ${ }^{21}$ w gruncie rzeczy chodzi o szacunek dla rodzin i bliskich: nie wolno bezcześcić zwłok, trzeba realizować przedśmiertne dyspozycje, ponieważ są bliscy zmarłego, którym na tym zależy, których można by urazić lub narazić na dyskomfort. W przypadku zwłok niepochowanych tych bliskich nie ma, nie ma więc żadnego powodu, by nie wykorzystać zwłok zgodnie

\section{Możliwość przekazywania decyzją administracyjną zwłok niepochowanych uczelniom} medycznym powinna zostać wykluczona.

o ile osoby te za życia wprost nie wyraziły sprzeciwu lub nie sprzeciwili się temu ich krewni. W praktyce oznaczało to, że samotny pensjonariusz szpitala, przytułku lub bezdomny musiał się liczyć z tym, że po jego śmierci jego ciało w majestacie prawa trafi na stół sekcyjny. Dlaczego? Ponieważ człowiek biedny, bezdomny, uzależniony od pomocy państwa lub dobroczynności nie zasłużył na szacunek lub wręcz zasłużył na karę za własne niedbalstwo i/lub lenistwo. W kolejnych nowelizacjach British Anatomy Act (lata 1872 i 1984) podtrzymano uprawnienia szkół medycznych do zwłok, po które nikt się nie zgłosił ${ }^{20}$. Naprawdę trudno znaleźć różnicę pomiędzy opisaną tu tradycją i pochodnymi wobec niej regulacjami a zapisaną w polskim prawie procedurą przekazywania niepochowanych zwłok wnioskującej uczelni medycznej decyzją właściwego starosty. Alternatywne wyjaśnienie swobody administrowania niepochowanymi zwłokami nie odwołuje się do etyczno-prawnego atawizmu - choć nie sposób uwolnić się od tego skojarzenia - zakłada jednak zupełnie różne od proponowanego w powyższych rozważaniach ugruntowanie obowiązku poszanowania zmarłych (oraz ich ewentualnej przedśmiert-

19 F. Tomasini, Research on the Recently Dead. An Historical and Ethical Examination, „British Medical Bulletin” 2008, t. 85, s. $7-16$.

20 S.C. Lawrence, Beyond the Grave... z bieżącymi potrzebami. Łatwo zauważyć, że takie rozwiązanie - podobnie jak w przypadku rozważanej przed chwilą możliwości apriorycznego przyznania rodzinie prawa do decydowania o losach zwłok przy braku przedśmiertnej woli zmarłego - kłóci się z uzasadnionym i przekonującym umocowaniem szacunku dla zmarłych w zasadach funkcjonowania podmiotu moralnego.

\section{Badania naukowe z wykorzystaniem ludzkich tkanek}

Drugim z sygnalizowanych na wstępie zagadnień jest pożądane doprecyzowanie sposobu wyrażania świadomej zgody na wykorzystanie tkanek w badaniach naukowych. Była już mowa o tym, że zgoda powinna stać się niezbywalnym warunkiem prowadzenia takich badań, chociażby ze względu na ogromny potencjał informacyjny wszelkich próbek biologicznych. W tym miejscu warto wymienić inne wysuwane na poparcie tego poglądu racje $\mathrm{e}^{22}$. Po pierwsze wskazuje się na to, iż wymóg uzyskiwania świadomej zgody gwaran-

21 Por. omówienie w Y.M. Barilan, Bodyworlds and the Ethics of Using Human Remains. A Preliminary Discussion, „Bioethics" 2006, t. 20, nr 5, s. 233-247.

22 Por. np. C. Grady i in., Broad Consent for Research with Biological Samples. Workshop Conclusions, „American Journal of Bioethics" 2015, t. 15 (9), s. 34-42. 
tuje/zwiększa przejrzystość zarówno samej donacji i procedur pozyskiwania próbek, jak i zasad ich wykorzystywania, co przekłada się na wzrost zaufania społecznego do badaczy, a co za tym idzie - na prawdopodobieństwo wzrostu liczby świadomych donacji. Po drugie chodzi zaś po prostu o zobowiązanie do poszanowania autonomii podmiotu - w tym jego prywatności i prawa do autokreacji - które konkretyzuje się przecież między innymi właśnie jako wymóg pozyskiwania świadomej zgody.

W rozważaniach dotyczących badań wykorzystujących zwłoki na pierwszy plan wysuwało się pytanie o powody, dla których w ogóle należy uwzględniać przedśmiertną wolę zmarłych, i - ze względu na pewną analogię do procedury donacji dla celów transplantacyjnych - o to, czy chodzi o wolę domniemaną, czy sprawy z mnogości i zróżnicowania badań wykorzystujących ludzkie tkanki, jak można przypuszczać, że zgoda na każde możliwe wykorzystanie próbki będzie jego świadomą decyzją? Dlatego też dyskusja sprowadza się w zasadzie do prób uzasadnienia wyboru jednej z dwóch form świadomej zgody: szerokiej lub dynamicznej (do zgody w postaci szczegółowej listy możliwych wykorzystań powrócę poniżej, traktuję ją bowiem jako uszczegółowienie ostatecznie wybranego modelu). Model szerokiej zgody zakłada, że podmiot wyraża zgodę na przyszłe wykorzystanie próbek, niemniej od razu zastrzega się, do jakich badań próbki z pewnością nie zostaną wykorzystane i o ile to potrzebne (i możliwe), gwarantuje się kolejny kontakt z dawcą; natomiast zgoda dynamiczna zakłada szereg kolejnych zgód na każde kolejne użycie próbki. Warto

\section{Zgoda powinna stać się niezbywalnym warunkiem} prowadzenia badań naukowych $\mathrm{z}$ wykorzystaniem tkanek, chociażby ze względu na ogromny potencjał
informacyjny wszelkich próbek biologicznych.

też faktycznie wyrażoną. Teraz zasadnicze znaczenie będzie miało pytanie o formę, jaką powinna przybrać rzeczywista, nie domniemana, zgoda podmiotu. Za apriorycznym przyjęciem modelu opt-in przemawia zarówno argument z przejrzystości procedur, jak i niejednokrotnie już wspominany potencjał informacyjny tkanek. Co więcej, nieprzebrana wielość i różnorodność prowadzonych badań odbiera jakikolwiek sens modelowi opt-out, który jest oparty na założeniu, że brak sprzeciwu to wyraz świadomej - a więc opartej na zrozumieniu wystarczającego zasobu informacji istotnych - decyzji podmiotu. Rzeczywista zgoda może przybrać formę zgody ogólnej (blanket consent), szerokiej (broad consent), dynamicznej (dynamic consent) lub listy (checklist). Na wstępie należy wykluczyć zgodę ogólną, wobec której można tu wysunąć analogiczny zarzut jak wobec modelu opt-out: skoro przeciętny potencjalny dawca nie zdaje sobie nawet przybliżyć najistotniejsze punkty w dyskusji porównującej oba te modele.

Szeroka zgoda na wykorzystanie próbek w badaniach naukowych powinna spełniać określone warunki. Po pierwsze, formularz zgody powinien określać spektrum badań, do których mogą zostać wykorzystane próbki (o ile to możliwe, informując, czy będzie chodzić o realizację celów terapeutycznych, czy komercyjnych), zwięźle opisywać warunki ich przechowywania i zasady udostępniania badaczom, a także uświadamiać potencjalnemu dawcy, iż jego tkanki są nośnikiem wielu informacji na temat jego stanu zdrowia. Po drugie, $w$ formularzu powinien znaleźć się opis określonych procedur ewaluacyjnych będących warunkiem rozpoczęcia kolejnych badań. Po trzecie wreszcie, formularz powinien zawierać gwarancję regularnego (o ile to możliwe) informowania dawcy o kolejnych procedurach badawczych 
oraz możliwości wycofania zgody na dalsze wykorzystywanie próbek ${ }^{23}$.

Przejdźmy do zwięzłego porównania zgody szerokiej $\mathrm{z}$ dynamiczną ${ }^{24}$. W modelu szerokim ponowna zgoda dawcy jest wymagana wyłącznie wtedy, gdy któryś kolejny program badawczy różni się od poprzednich pod istotnym - z etycznego punktu widzenia względem. W modelu dynamicznym ponownej zgody wymaga się przy każdym nowym projekcie; uwagę dawców zaprząta się więc nawet w sytuacjach, gdy chodzi o rozpoczęcie kolejnego, zasadniczo nieróżniącego się od poprzednich, projektu. Mimo iż probant uzyskuje więcej informacji, w większości przypadków nie są to informacje istotne. Zwraca się uwagę, że model dynamiczny przenosi większy ciężar oceny etycznej na probantów, od których wymaga się kolejnych świadomych wyborów, zarazem jednak niejako usypia ich czujność i prowadzi do bezrefleksyjnego automatyzmu decyzyjnego. Natomiast szeroka zgoda z jednej strony pozwala dawcy panować nad tym, czy jego próbki w ogóle będą wykorzystywane w badaniach, $\mathrm{z}$ drugiej zaś minimalizuje obciążenia proceduralne. Zakładając więc, iż (1) badania wykorzystujące tkanki ludzkie stwarzają niewielkie ryzyko dla dobrostanu dawcy, (2) warunkiem ich rozpoczęcia jest pomyślny wynik oceny etycznej, a (3) jakakolwiek zmiana warunków wstępnych wymaga ponownej decyzji dawcy, model dynamiczny gwarantujący mu większą kontrolę niż szeroka zgoda nie ma nad nią realnej przewagi ${ }^{25}$.

Naturalnie przedstawione wyżej uwagi odnoszą się bezpośrednio do zasad gromadzenia ludzkich tkanek w biobankach i wykorzystywania próbek już zgromadzonych. Niemniej nie widać powodu, by nie przenieść wniosków do dyskusji nad wykorzystywaniem tkanek pozyskiwanych przy okazji różnego rodzaju procedur terapeutycznych. Sytuacja jest o tyle prostsza, że najprawdopodobniej będzie tu chodziło nie tyle o serię niedookreślonych procedur badawczych, ale o użycie w konkretnych projektach badawczych.

23 Por. np. tamże.

24 K.S. Steinsbekk, B. Kåre Myskja, B. Solberg, Broad Consent versus Dynamic Consent in Biobank Research. Is Passive Participation an Ethical Problem?, „European Journal of Human Genetics” 2013, t. 21 (9), s. 897-902.

25 C. Grady i in., Broad Consent for Research..., s. 34-42.
Można oczywiście zapytać, czy ta różnica jest na tyle istotna, by powrócić do modelu opt-out i założyć, że każdy pacjent wyraża domniemaną zgodę na zagospodarowanie pozostawionych w placówce bezużytecznych „odpadów”. Moim zdaniem rozstrzygające są tu przytoczone już powyżej racje: ogromny potencjał informacyjny próbek biologicznych, z którego wielu ludzi - jeśli nie większość - nie zdaje sobie sprawy, powoduje, że obowiązek poszanowania autonomii podmiotu (wraz z wbudowanym weń zobowiązaniem poszanowania prywatności) powinien się w tej sferze skonkretyzować w formie rzeczywistej, nie domniemanej, zgody. Bardziej zasadne byłoby rozważenie, czy w przypadku tkanek będących po prostu efektem ubocznym procedur medycznych sensowniejsze nie byłoby wprowadzenie zgody w formie wyczerpującej listy konkretnych zastosowań. Ze względów pragmatycznych takie rozwiązanie wydaje się lepsze, jeśli chodzi o tkanki, które nie były / nie są / nie będą gromadzone w biobankach, ale są po prostu wykorzystywane w konkretnych, już określonych badaniach.

\section{Wnioski}

Z powyższej prezentacji wyłania się jasna sugestia dotycząca pożądanego, z etycznego punktu widzenia, sposobu doprecyzowania przepisów regulujących zasady gromadzenia szeroko rozumianego ludzkiego materiału biologicznego (tkanek, części ciała, zwłok) do badań naukowych. Niezależnie od tego, czy chodzi o zwłoki, części ciała, czy tkanki, powinno się to odbywać w oparciu o zgodę dawcy (donatora), która musi być zgodą rzeczywistą, a nie domniemaną. Zobowiązanie do poszanowania autonomii podmiotu - w tym jego prywatności - oraz szacunek jako preferowana wartość w relacji żywych do zmarłych wykluczają możliwość swobodnego, podyktowanego wyłącznie skalą zapotrzebowania, dysponowania materiałem biologicznym niezależnie od tego, czy pochodzi on od dawców żywych, czy zmarłych. Z kolei wielość i różnorodność prowadzonych badań (z których część budzi poważne kontrowersje) wyklucza możliwość zastosowania modelu opt-out opartego na założeniu, iż brak sprzeciwu jest przejawem świadomej decyzji, a nie niewiedzy czy niedbalstwa podmiotu. Jeśli chodzi o konkretną formę, jaką powinna przybrać wyrażona przez dawcę (donatora) zgoda, na pewno 
zawsze wtedy, gdy mowa o pośmiertnym wykorzystaniu materiału biologicznego (badania $\mathrm{z}$ użyciem zwłok, ale także tkanek i części ciała) - a więc nie ma możliwości ponownego kontaktu $\mathrm{z}$ dawcą - powinna być to zgoda $\mathrm{w}$ formie listy potencjalnych sposobów wykorzystania, gdzie dawca zaznacza te, na które się zgadza. W sytuacji, gdy materiał jest wykorzystywany w badaniach prowadzonych za życia dawców, dopuszczalna jest także, a niekiedy wręcz preferowana, tzw. szeroka zgoda. Ponownie chciałam też podkreślić, iż zapisana w polskim prawie swoboda administrowania zwłokami niepochowanymi w moim przekonaniu nie znajduje zadowalającego etycznego umocowania.

\section{Bibiografia}

Andrews L.B., Do the Dead Have Interests? Policy Issues for Research After Life (with D. Nelkin), „American Journal of Law \& Medicine” 1998, t. 24, nr 261, http://scholarship.kentlaw.iit.edu/fac_schol/10 (dostęp 29.07.2019).

Barilan Y.M., Bodyworlds and the Ethics of Using Human Remains. A Preliminary Discussion, „Bioethics” 2006, t. 20, nr 5, s. 233-247.

Baum Levenbook B., Harming Someone after His Death, „Ethics” 1984, t. 94, nr 3, s. 407-419.

Baum Levenbook B., Harming the Dead, Once Again, „Ethics” 1985, t. 95, nr 1, s. 162-164.

British Association of Biological Anthropology and Osteoarchaeology, Code of Ethics, BABAO Working Group for ethics and practice 2010, https://www.babao.org.uk/assets/UploadstoWeb/codeofethics.pdf (dostęp 29.06.2019).

Callahan J.C., On Harming the Dead, „Ethics” 1987, t. 97, nr 2, s. 341-352.

Feinberg J., The Moral Limits of the Crime Law, t. 1: Harm to Others, New York [Oxford University Press] 1987.

Grady C. i in., Broad Consent for Research with Biological Samples. Workshop Conclusions, „American Journal of Bioethics” 2015, t. 15 (9), s. $34-42$.
Haberko J., Dwugłos w sprawie dopuszczalności badań naukowych $z$ wykorzystaniem ludzkiego materiału biologicznego. Perspektywa prawna, „Forum Prawnicze” 2020, nr 59, s. 3-15. Harris J., Organ Procurement. Dead Interests, Living Needs, „Journal of Medical Ethics” 2003, t. 29, s. 130-134.

Iserson K.V., Life versus Death. Exposing a Misapplication of Ethical Reasoning, „Journal of Clinical Ethics” 1994, t. 5, s. 261-264. Lawrence S.C., Beyond the Grave. The Use and Meaning of Human Body Parts. A Historical Introduction, „Faculty Publications, Department of History, University of Nebraska - Lincoln” 1998, January, s. 111-142.

Partridge E., Posthumous Interests and Posthumous Respect, „Ethics” 1981, t. 91, nr 2, s. 243-264.

Pentz R.D. i in., Ethics Guidelines for Research with the Recently Dead, „Nature Medicine” 2005, t. 11, nr 11, s. 1145-1149.

Steinsbekk K.S., Kåre Myskja B., Solberg B., Broad Consent versus Dynamic Consent in Biobank Research. Is Passive Participation an Ethical Problem?, „European Journal of Human Genetics” 2013, t. 21 (9), s. 897-902.

Szewczyk K., Bioetyka, Pacjent w systemie opieki zdrowotnej, Warszawa [Wydawnictwo Naukowe PWN] 2009.

The National Committee for Research Ethics on Human Remains, Guidelines for Research Ethics on Human Remains, The Norwegian National Research Ethics Committees, English edition, July 2016.

Tomasini F., Research on the Recently Dead. An Historical and Ethical Examination, „British Medical Bulletin” 2008, t. 85, s. 7-16.

Wicclair M.R., De Vita M.A., Oversight of Research Involving the Dead, „Kennedy Institute of Ethics Journal” 2004, t. 14, nr 2, s. 143-164.

Wicclair M.R., Ethics and Research with Deceased Patients, „Cambridge Quarterly of Healthcare Ethics” 2008, t. 17, s. 87-97.

Wicclair M.R., Informed Consent and Research Involving the Newly Dead, , Kennedy Institute of Ethics Journal” 2002, t. 12, s. 351-362.

Wilkinson T.M., Last Rights. The Ethics of Research on the Dead, „Journal of Applied Philosophy” 2002, t. 19, nr 1, s. 31-41. 